\title{
The influence of dimensions of organisational culture on supply chain performance in selected state-owned enterprises in Zimbabwe
}

\begin{tabular}{|c|c|}
\hline \multicolumn{2}{|c|}{$\begin{array}{l}\text { Authors: } \\
\text { Michael Musanzikwa }{ }^{1} \text { ( } \\
\text { Manduth Ramchander }\end{array}$} \\
\hline \multicolumn{2}{|c|}{$\begin{array}{l}\text { Affiliations: } \\
\text { }{ }^{1} \text { Department of Supply } \\
\text { Chain Management, Chinhoyi } \\
\text { University of Technology, } \\
\text { Zimbabwe }\end{array}$} \\
\hline \multicolumn{2}{|c|}{$\begin{array}{l}{ }^{2} \text { Department of Operations } \\
\text { and Quality Management, } \\
\text { Durban University of } \\
\text { Technology, South Africa }\end{array}$} \\
\hline \multicolumn{2}{|c|}{$\begin{array}{l}\text { Corresponding author: } \\
\text { Manduth Ramchander, } \\
\text { manduthr@dut.ac.za }\end{array}$} \\
\hline \multicolumn{2}{|c|}{$\begin{array}{l}\text { Dates: } \\
\text { Received: } 18 \text { Mar. } 2018 \\
\text { Accepted: } 08 \text { July } 2018 \\
\text { Published: } 13 \text { Sept. } 2018\end{array}$} \\
\hline \multicolumn{2}{|c|}{$\begin{array}{l}\text { How to cite this article: } \\
\text { Musanzikwa, M. \& } \\
\text { Ramchander, M., 2018, } \\
\text { 'The influence of dimensions } \\
\text { of organisational culture on } \\
\text { supply chain performance } \\
\text { in selected state-owned } \\
\text { enterprises in Zimbabwe', } \\
\text { Journal of Transport and } \\
\text { Supply Chain Management } \\
\text { 12(0), a392. https://doi.org/ } \\
\text { 10.4102/jtscm.v12i0.392 }\end{array}$} \\
\hline \multicolumn{2}{|c|}{$\begin{array}{l}\text { Copyright: } \\
\text { (c) 2018. The Authors. } \\
\text { Licensee: AOSIS. This work } \\
\text { is licensed under the } \\
\text { Creative Commons } \\
\text { Attribution License. }\end{array}$} \\
\hline \multicolumn{2}{|l|}{ Read online: } \\
\hline 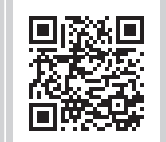 & $\begin{array}{l}\text { Scan this QR } \\
\text { code with your } \\
\text { smart phone or } \\
\text { mobile device } \\
\text { to read online. }\end{array}$ \\
\hline
\end{tabular}

Background: Despite being strategic, state-owned enterprises (SOEs) have failed to fulfil their mandate. Supply chain performance is ineffective largely because of weak organisational culture.

Objectives: To explore the extent to which organisational cultural factors have influenced the supply chain performance of SOEs, review the literature; effectiveness of attaining financial targets, customer satisfaction, internal business processes, learning and growth; time orientation on the supply chain metric of delivery. The supply chain metric of flexibility; profitability on cost reduction; 'no ownership' culture on decision-making; and the level of customer satisfaction.

Method: A mixed-method was used. The population comprised managers, employees and clients of eight selected SOEs. Judgmental, random and convenience sampling were employed. Questionnaires and interviews were the research instruments and quantitative and qualitative analyses were conducted. Findings are presented thematically, in line with the research questions.

Results: SOEs were not meeting financial targets, not satisfying customers, poor internal business processes not attaining learning and growth targets. Organisational cultural variables were weak; affecting flexibility, no timely delivery of goods and services. Also influenced the behaviour of human resources and an indirect effect on customer satisfaction, cost-saving and profitability in the SOEs.

Conclusion: The SOEs failed to meet financial, customer, learning and growth targets. The internal business processes were not effective. The culture did not promote efficiency. The study recommends that commitment of leadership on human behaviour is necessary for effective supply chain performance and strategy implementation. Constant environmental scanning, strategic alliances, rationalisation of remuneration and sound corporate governance are essential.

\section{Introduction}

In most of the public sector institutions around the world there has been a problem of underperformance, and weak organisational culture seems to be the problem (Rondinelli 2005). According to Burman and Evans (2008), challenges that state-owned enterprises (SOEs) face in supply chain (SC) performance could be a result of organisational cultural practices that are counter-productive. There are a myriad of organisational cultural variables but the selected ones seem to have a more direct influence on SC performance in the SOEs.

State-owned enterprises are government-owned entities, and in Zimbabwe they include Air Zimbabwe, the Zimbabwe Electricity Supply Authority (ZESA) and the National Railways of Zimbabwe (NRZ). There are 78 SOEs in Zimbabwe, which are expected to be either the backbone of the Zimbabwean economy or economic enablers. The effectiveness in SC performance in SOEs should ultimately result in several spillover effects, leading to improvement in the quality of life of all Zimbabweans (Nyoni 2012). In general, SOEs are strategic institutions and governments establish them so that basic services are available to all the citizens. Most SOEs aim to provide essential services such as water, electricity, transport and communication, and they are viewed as strategic institutions.

Baily et al. (2008) define the SC as all those involved in organising and converting materials through the input stages (raw materials), conversion phase (work in progress) and outputs 
(finished products). Wieland and Wallenburg (2011) define SC management (SCM) as a collection of related business functions conducted in order to provide goods and services required by clients. Governments have a constitutional mandate to ensure that there is provision of goods and services and they do this through SOEs (Burman \& Evans 2008).

However, in Rondinelli's (2005) view, most of the SOEs in developing countries are failing to contribute to economic development. Most of the government-owned entities are not effective in SC performance and are loss makers instead of revenue generators. For example, the Chinese government invested more than $\$ 11$ billion into SOEs during the 1990s, but he results of the investment were disappointing (Woetzel 2008). In addition, Schlettwein (2010) showed that the state-owned entities in Namibia were contributing only $0.7 \%$ to the national revenue while the government was injecting about $9 \%$ of total government expenditure. The arguments by Woetzel (2008) and Schlettwein (2010) show that, despite the investment of resources in the SOEs, the entities were failing to fulfil their mandate and not making any return on investment.

According to Burman and Evans (2008), infectiveness in SOEs results from the 'organisational culture' inherent in the institutions. Along similar lines, Islam and Michael (2009) opine that SOEs are organisations that belong to nobody and there is no concern about effectiveness in SCM. The culture in organisations determines the behaviour of members and their commitment towards goal attainment. According to this view, Schein (2009) argues that organisational culture is a set of beliefs, values and assumptions that hold organisations together. In a similar vein, Ravasi and Schultz (2006) state that the culture of an organisation denotes the shared values that guide the behaviour of its stakeholders, particularly its managers and employees. Culture entails the beliefs, values, practices and attitudes that have been cultivated within organisational members over a long period of time (Schein 2010).

According to Woetzel's (2008) study of Chinese SOEs, most of the institutions owned by the government are highly inefficient. Schlettwein (2010) points out that there is no 'drive' towards realisation of profits, because, by their nature, profits are meant to fulfil social obligations. Along similar lines, government-owned entities in Zimbabwe are perennial loss makers (Nyoni 2012). For instance, in 2009, the Reserve Bank of Zimbabwe (RBZ) indicated that SOEs like Air Zimbabwe, ZESA, NRZ and the Zimbabwe National Roads Administration were underperforming and there were inadequacies in their SC that were draining the national purse. In addition, Nyoni (2012) labelled the SOEs as the 'missing link' in the economic turnaround of Zimbabwe. Most of them have been performing negatively and have a negative effect on the treasury, thereby affecting the economic growth of the country (RBZ 2009).

According to the RBZ (2009), a lack of commitment and a weak organisational culture are largely to blame for the ineffective performance of the SOEs. The Zimbabwe Independent (2013) also shared the same sentiments and reported that there were delays in decision-making (time orientation), with public procurement systems being slow. By way of example, delays in decision-making resulted in the City of Harare paying $\$ 80$ million instead of around $\$ 10 \mathrm{~m}$ for the construction of the airport road, a distance of less than $20 \mathrm{~km}$. In addition, the need to comply with state procurement procedures resulted in the construction of a $\$ 600000$ district hospital in Gokwe North lagging behind schedule (Mafumbe 2011). According to Masuku (2011), delays were a major issue in the customer service performance, as most service providers were unhelpful, rude and inattentive, and the speed of service was generally slow.

Mafumbe (2011) also points out that four SOEs, namely Air Zimbabwe, the National Oil Company of Zimbabwe, NRZ and the Grain Marketing Board (GMB) had a combined loss of US $\$ 40.9 \mathrm{~m}$ during a period of six months, from January to June 2010. The value of the loss was substantial given that the gross domestic product (GDP) of Zimbabwe during that time was about $\$ 10 \mathrm{bn}$ (Zimbabwe National Statistical Agency 2012). It would appear that SOEs had been underperforming and failed to contribute meaningfully to the economic growth of the country.

The primary aim of this study was to explore the influence of dimensions of organisational culture like time orientation, profit orientation and the 'no ownership' culture on SC performance in SOEs in Zimbabwe. The specific objectives were as follows:

- to conduct a literature review to understand the theoretical, conceptual and empirical underpinnings of the dimensions of organisational culture

- to assess the performance of SOEs in Zimbabwe in terms of financial, customer, internal business processes and learning and growth perspectives

- to understand the influence of time orientation on the SC metric of delivery in SOEs in Zimbabwe

- to understand the influence of time orientation on the SC metric on the flexibility of SOEs in Zimbabwe

- to understand the influence of profit orientation on cost reduction in SC activities in SOEs in Zimbabwe

- to understand the influence of the no-ownership culture on decision-making in SCM in SOEs in Zimbabwe

- to understand the level of customer satisfaction in selected Zimbabwean SOEs.

\section{Theoretical and conceptual frameworks}

The study used four theories, all of which were derived from the literature. The conceptual framework shows the main variables in the study and was designed by the researcher.

\section{Theoretical framework}

The research used four theories in order to establish the influence of culture on SC performance in SOEs in Zimbabwe. The first theory was cultural theory, which provides a 
framework to understand and explain the concept of organisational culture (Shahzad, Luqman \& Khan 2012). According to Quy (2011), corporate culture pertains to the norms and ways of doing things in organisations. Organisational culture influences the behaviour of human resources, the most valued assets in institutions.

The second theory is the balanced score card (BSC). Kaplan and Norton (1992) developed the BSC as a tool for thoroughly examining the SC performance of companies. There are four perspectives in the BSC: financial, customer and internal business processes and learning and growth. According to Mehrjerdi (2009), the BSC incorporates both financial and non-financial elements and provides a 'balanced' means of assessing SC performance.

The third theory is the Customer Satisfaction Index (CSI). The ability of the organisation to meet the needs of the customers results in customer satisfaction (Denzin 2008), which helps to keep and draw more clients (Grant 2008). As Chin (2010) observes, there are several ways of pleasing customers, such as employee empowerment, provision of adequate resources and the training and development of employees, which promote good employee-customer relations within the organisation. One method that has been used for a long time by managers to measure the level of client satisfaction within an organisation is the Customer Satisfaction Index (CSI). The CSI assesses many indicators that relate to customer service, namely those relating to the effectiveness of a service, client care, dealings, methods, systems, pricing mechanisms and the goods and services provided (Lamikanra 2013). The client service factors are indicated in Figure 1.

According to Figure 1, customer satisfaction is the result of a combination of factors. Management should therefore be aware that satisfying the needs of clients is a complex process.

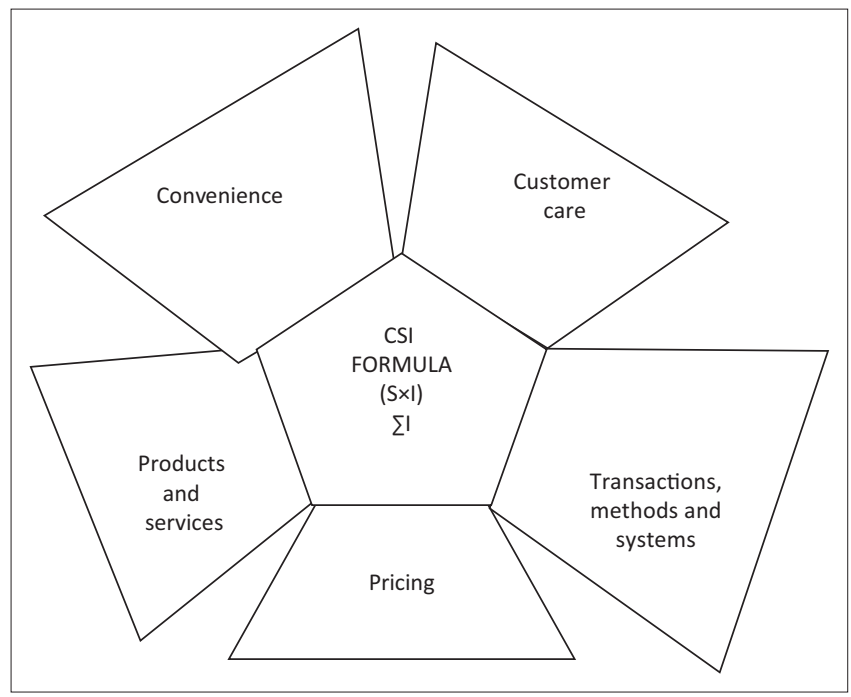

Source: Lamikanra, S., 2013, African Banking Industry Customer Satisfaction Survey, KPMG Lagos

FIGURE 1: Customer service factors. S, satisfaction; I, importance; CSI, Customer Satisfaction Index.
The fourth theory is the service quality (SERVQUAL) model that was developed by Parasuraman, Zeithamal and Berry (1985). The SERVQUAL model states that there are gaps between the expectations of clients and the services that are delivered by organisations. Customer satisfaction will depend on the extent to which the gaps between the views of the clients and those of organisations are reduced.

\section{Conceptual framework}

The thrust of this research was to examine the influence of selected dimensions of organisational culture (time, ownership and profit orientation) on SC performance in selected SOEs in Zimbabwe. The importance of SCM is to contribute to the overall success of the organisation through aligning the strategic, tactical and operational activities to attain optimal performance (Bhagwat \& Sharma 2007). Supply chain management is also important in providing or creating value for the customers (Chemangich 2013).

The dimensions of organisational culture, that is, time, ownership and profit orientation, were the independent or causal variables, while SC performance (financial performance, customer satisfaction, efficiency in internal business processes and learning and growth) was the dependent variable or the outcome. Human behaviour, flexibility, delivery and quality were the intervening variables. The study focused on the SC metrics of flexibility, delivery and quality because they are critical in ensuring organisational success and customer satisfaction. Figure 2 illustrates the variables in the conceptual framework.

According to Figure 2, the organisational cultural variables (time orientation, ownership orientation and profit orientation) are perceived to have a significant influence on human behaviour. According to Armstrong (2008), humans are the essential resources in any organisation and their attitudes influence SC performance in the organisations. Accordingly, human resources in the Zimbabwean SOEs are perceived to have an influence on SC matrices of flexibility, delivery and quality. In the end, flexibility, delivery and quality have an influence on the performance of the organisation in terms of financial targets, customer satisfaction, internal business processes, and learning and growth.

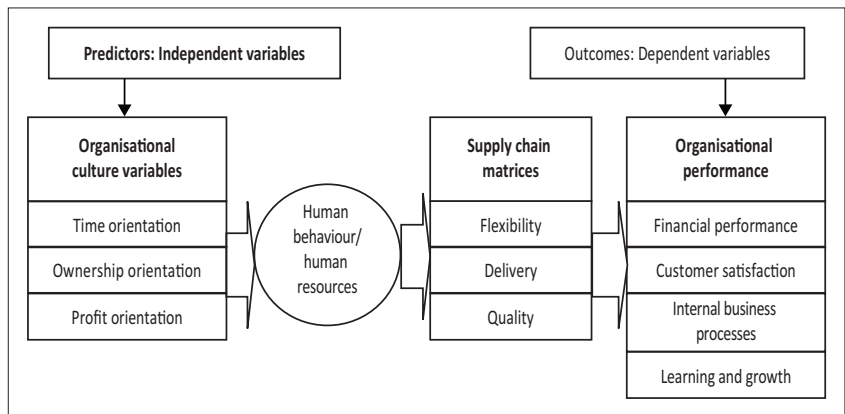

FIGURE 2: Conceptual framework. 


\section{Literature review}

\section{The concept of organisational culture}

Schein (2009) described organisational culture as a general pattern of behaviour that organisations adopt. As a concept, he argues that it involves the sharing of basic norms, principles and beliefs by individuals in an organisation. Zhang (2009) has observed that organisational culture is a collective behaviour, as employees in an organisation have adopted these norms collectively. The organisation's vision, mission, systems, dress code, artefacts, language used, corporate colours and symbols form the culture of the organisation. Quy (2011) has further acknowledged that culture is the norms imparted to new organisational members so that they can adopt the patterns of the organisation. Organisational culture influences the way employees interact among themselves, with clients and key stakeholders. Ravasi and Schultz (2006) have argued that organisational culture are the collective norms, psychologically shared, that guide the behaviour of employees and their decision-making capacity in various situations that may arise.

Organisational culture in developed and developing countries tends to vary. One cultural aspect that varies is the extent to which informal processes influence organisations. Organisations in African countries, for instance, are influenced mainly by informal organisational systems. There are strong extended family and kinship ties, which seem to influence decisions in organisations (Omoyefa 2008). It is not surprising, therefore, to find an organisation made up of related individuals in Zimbabwe or for work-related issues to be discussed and important decisions to be made during family gatherings (Biti 2011). The culture seems to be different in most European countries, where there are no strong extended family ties or kinship identities.

Organisational culture seems to influence the performance of an organisation and the extent of customer satisfaction (Peterson 2012). Cultural dimensions such as time orientation, profit orientation and ownership orientation influence delivery, flexibility, quality, cost and decision-making. Delivery can be measured in terms of lead and cycle time. Flexibility can be measured in terms of ability to respond to different needs of clients. Quality may be assessed in terms of functionality, conformance and reliability. Finally, decisionmaking can be measured in terms of the time taken to make decisions and their influence on organisational performance (Quy 2011). The tendency in developing countries is apparently to be slow and rigid, with an emphasis on the welfare of employees, while in developed countries emphasis seems to now be on efficiency, and organisations seem to have rejuvenated the scientific management prescriptions and are now more concerned about high output (Peterson 2012).

Although there are several organisational cultural dimensions, this study focuses on time orientation, flexibility, delivery, profit and ownership orientation.
Time orientation: Time is a crucial dimension of organisational culture. Organisations value time, as time wasted is money wasted and it is often very difficult to recover wasted time. The variations in how people handle time are associated with underlying beliefs and values regarding the timely performance of tasks (Peterson 2012). One can argue that the temporal orientation of people, seen in a cultural context, can be best defined as a continuum of perceptions ranging from monochronic to polychronic orientations (Chin 2010). According to Zhang (2009), people who are monochronic are very time conscious, and their work behaviour and approaches are regulated according to time. The behaviour and approaches of people from the polychronic group are based mainly on their relationships. They can perform different activities concurrently and believe in being flexible rather than adopting a rigid structure (Quy 2011). As a result of people's relationship to their cultural backgrounds and their link to time, it was observed that people's values impact on the way they consider time in relation to what they want to do at any given moment (Zhang 2009).

Flexibility and delivery: Flexibility and delivery relate to responding to customer needs. To satisfy customers, an organisation has to be responsive to their needs. An organisation satisfies customers by being efficient and effective in meeting their needs. The organisation should prioritise customer needs and provision of quality services (Chin 2010). Traditionally, in a market-oriented culture, the customer is the primary focus of any organisation. Customer needs take centre stage during the strategic planning and routine decision-making processes of a market-oriented firm (Chin 2010).

Profit and ownership orientation: Ownership structure influences the extent to which management is committed towards realising profits. State-owned enterprises, by being owned by government, are characterised by a no-ownership culture, thereby limiting the drive towards profit-making (Biti 2011). According to Omoyefa (2008), loss-making in the SOEs highlighted the need for privatisation, a marked feature of the structural adjustment programmes (SAPs), which were intended to improve the efficiency of SOEs. The governments of third world countries need to consider privatising all nonperforming SOEs. Most governments embarked on extensive privatisation during the SAPs in the 1990s as a strategy of 'rolling back the big arm' of the government in the economy. The major aims of privatisation were to promote economic growth by reducing the role of the state, reducing the budget deficit and dealing with corruption within the heavily bloated public sector (Rondinelli 2005). By 1996, most countries had privatised their SOEs even though the privatisation initiatives produced lukewarm results (Zhang 2009).

\section{Human behaviour as an important aspect of organisational culture}

According to Dessler (2005), the most important asset in any organisation is its human capital. The unique nature of each 
individual affects the culture of the organisation. Humans differ in their decision-making capabilities, emotions and character, behaviour, attitude, perceptions and working abilities. The importance of human resources, being rooted in some theories, has made the study of organisational behaviour pertinent. Management henceforth has to invest much time in trying to break down and understand these individual complexities so that their planning, organising, leading and controlling functions are informed by individual and group dynamics. Most organisational problems are rooted in how individuals interact, relate, react, communicate and cooperate within and outside the organisation (Armstrong 2008).

\section{The concept of supply chain management}

Supply chain management is a process comprising all the activities involved in the transformation of raw materials to a finished product or service to be used by an end user (Johnson \& Scholes 2010). Along similar lines, Lambert (2008) describes SCM as the systematic and strategic coordination of business functions in order to ensure delivery of quality goods and services to customers. Chandrasekaran (2010) is also in agreement with Johnson and Scholes (2010) and Lambert (2008) that SCM involves the business functions of procurement, logistics (outbound and inbound transportation), inventory management and information management. Bose and Thomas (2007) point out that SCM is the integration of key business processes across the SC to create value for customers and stakeholders. There are several metrics of SCM but this research focused on delivery, flexibility and quality.

- Delivery: Delivery is an important aspect of SCM. Delivery can be measured in terms of lead and cycle time (Clarke 2007). Fast, reliable delivery requires shorter lead times and the achievement of variety reduction (Larbi 2006). By nature, delivery capability is cross-functional, regarding the areas of sourcing, operations and logistics (Nambirijan \& Kumar 2010). According to Clarke (2007), delivery is about ensuring that products and services reach the customers at the right time. Effective delivery is a critical aspect of customer satisfaction and organisations should eliminate bottlenecks that compromise the process.

- Flexibility: According to Allio (2005), flexibility is the capability to adapt to new, different or changing requirements and an openness to new ideas and changes, which can be measured by the ability to respond to different needs of clients. A flexible organisation operates with shorter lead times and is very responsive to customer requests (Ralston et al. 2008).

- Quality: According to Chin (2010), quality is fitness for purpose and is concerned with satisfying the needs of clients. Grant (2008) defines quality in terms of functionality, conformance and reliability. One of the tools for guaranteeing the quality of goods and services is total quality management (TQM). Johnson and Scholes (2010) define TQM as a strategic tool for enhancing business performance by working with other people in order to meet customer requirements at minimum cost, while maintaining improved product, services and business processes among the employees of the organisation (Grant 2008). Total quality management can be viewed as revolutionising the management system with a view to creating continuous value to customers through the adoption of new designs and organisational technologies, systems and processes (Denzin 2008).

\section{Cross-country case studies}

We evaluated cross-country case studies from five countries: China, South Korea, Vietnam, Namibia and Nigeria. The case studies were expected to be lessons for the SOEs in Zimbabwe. The countries were selected because their past and current economic environments have similarities to Zimbabwe.

\section{State-owned enterprises in China}

In China, the absence of a strong, performance-oriented culture resulted in the government making a paradigm shift on how to treat the SOEs (Quy 2011). Woetzel (2008) argues that the Chinese government privatised and commercialised most SOEs, and the directors of SOEs were held more accountable for their successes and failures. In short, SOEs in China underwent a cultural change process. In addition, Ralston et al. (2008) studied SOEs in China and concluded that there has been a transformation in the culture of these institutions and that organisational culture has been the indicator of change in SOEs. In addition, because of cultural change, there has been a marked improvement in SCM in SOEs in China. In fact, corporations outside China are increasingly seeing the country's open SOEs as partners in global markets (Quy 2011).

\section{State-owned enterprises in South Korea}

Beginning in the 1980s, the performance of SOEs in South Korea was dismal. The government was hesitant to privatise the SOEs (Kim 2007). Government policymakers had no option but to privatise. The SOEs were draining the government resources while posing a political threat to the politicians. Most enterprises were underperforming. Privatisation was the only way out. The government had to 'cut its big arm' within the economy (Kim 2007). The underperformance of SOEs resulted in privatisation; the economic meltdown of 1998 resulted in a revolution in the economic policies of South Korea. The Korean government had to give up its major shares in most of the enterprises (Quy 2011). The new private owners brought a new philosophy of doing things that emphasised profits, a move away from the traditional way of doing things. In short, public sector management reforms like liberalisation, privatisation, civil service reforms and performance management entail a change in the culture of institutions.

\section{State-owned enterprises in Vietnam}

According to Quy (2011), SOEs in Vietnam used to have a weak culture because they were operating as monopolies. In areas like the energy sector, sanitation and health welfare, 
therefore, the managers in SOEs were 'sleeping'. Customer needs were not prioritised and the enterprises planned without incorporating the views of the consumers (Quy 2011). However, in 2005, Vietnam joined the World Trade Organization and there was an 'opening of borders' and privatisation of some of the SOEs. The deregulation process resulted in the SOEs being able to recognise the importance of customer loyalty as the Vietnamese government allowed private companies to enter the former monopolised markets (Kim 2007). Thus, the SOEs had to change their internal environment to adapt to the new situation (Quy 2011).

\section{State-owned enterprises in Namibia}

Schlettwein (2010) believed that culture was largely to blame for SCM challenges in SOEs in Namibia. Schlettwein (2010) highlighted that between the years 2000 and 2010, the government of Namibia received not more than $1 \%$ of revenue from SOEs. For instance, in the 2008-2009 accounting year, revenues collected amounted to $\mathrm{N} \$ 173.4 \mathrm{~m}$ in dividends, an amount that represented only $0.7 \%$ of the total revenues collected in that fiscal year. This was against an investment of $9 \%$ of the government expenditure on SOEs. The expenditure amounted to N\$1.9bn (Schlettwein 2010). In light of the nonperformance of SOEs in Namibia, it decided to change the culture in SOEs. In order to enhance performance, it was resolved that board members would be selected based on merit, the recruitment process had to be transparent and nepotism would not be tolerated. The Namibian government saw the importance of improving the values, norms and efficiency of SOEs. It enhanced organisational culture through cultivating an innovative mentality, promoting cost-cutting measures, service quality, risk-management and innovativeness in the sector (Schlettwein 2010).

\section{State-owned enterprises in Nigeria}

The 'no-owner company' culture of SOEs, or the principle 'what belongs to the state belongs to nobody', accounted for challenges in the Nigerian SOEs (Omoyefa 2008). Jerome (2008) pointed out that the expansion of SOEs in Nigeria contributed positively towards economic recovery. There was a reduction of the deficit and the burden on the government's budget. However, before the movement towards privatisation, government enterprises had failed to deliver quality services. The loss-making enterprises worsened the debt crisis in most African countries. By 1985, SOEs had accrued heavy deficits and the burden was heavy on the economy of Nigeria. The enterprises' expenditure was about US\$35bn, consisting of equity and government loans and grants. It was devastating that the returns consisted of only about US\$1.5bn from around 1980 to 1987 (Jerome 2008). The losses of the SOEs were bleeding the economy and the toll on the country's budget was not sustainable. The Nigerian SOEs were 'sleeping giants'.

\section{Research methodology}

Both positivist and interpretive thinking guided this study. The researcher sought to understand the influence of organisational cultural variables on SC performance and customer satisfaction while generating new knowledge. This was in line with the positivist philosophy, which states that the search for knowledge is continuous (Saunders, Lewis \& Thornhill 2012). In line with the interpretive approach, people have subjective views about organisational cultural variables, and their perceptions of customer satisfaction may differ. The researcher therefore used the mixed methods approach, that is, a combination of both qualitative and quantitative designs (Creswell 2014). Recognising the epistemological chasm between qualitative and quantitative methods, the researcher made no assumptions about the convergence of data. The multi-method approach was adopted because this approach makes it possible to generate a more complete set of data. The population for this study comprised of managers, employees and clients of eight SOEs in Zimbabwe. The sample sizes of managers, employees and clients were 1724, 12953 and 16.8 million, respectively. The combined population size was 16.81 million. There were multiple counts when it came to clients, because one person could be a client in all eight SOEs, meaning that the contribution of that person to the population would be eightfold.

A combination of sampling strategies was used. To select the SOEs, the judgmental sampling method was used. Table 1 shows the SOEs studied and justification for their inclusion.

The participants were grouped into three categories, comprising managers, employees and clients. Managers and employees were selected using random sampling, while clients were selected through convenience sampling. The proportion of the sample size as compared to the population size was $10 \%$ for the managers and $5 \%$ for the employees. The sample size for clients was about $0.0025 \%$ of the population, or one in every 40000 individuals. The sample comprised 176 managers, 470 employees and 421 clients, or 1067 elements. The sample sizes were manageable and were deemed adequate to yield the required data because they exceeded the minimum samples sizes for the respective population sizes if the confidence level was at 95\%. According to the Research Advisory Council (2006), the minimum sample size for a population of up to 300 million at $95 \%$ confidence level and with a 5\% margin of error is 384 . In addition, Sekeran and Bourgie (2010) affirm that any sample size above 384 is acceptable for very large populations.

Questionnaires and interviews were used as research instruments. There were two sets of questionnaires. One of the questionnaires was administered to clients to capture their perceptions of customer satisfaction. The questionnaire for clients had six sections. The first section had personal details (gender, age, qualifications and number of years as a client). The other sections of the questionnaire for the clients was designed in line with the components of the CSI model, which are convenience of products or services, customer care, transactions, methods and systems, pricing, and products and services. The questionnaire administered to managers and employees also had six sections. The first section had personal details (gender, age, occupation, qualifications, tenure of employment). The other sections focused on dimensions of 
TABLE 1: Zimbabwean state-owned enterprises studied and justification for inclusion.

\begin{tabular}{|c|c|}
\hline Name of SOE & Justification for inclusion in the study \\
\hline Air Zimbabwe & This SOE is vital for facilitating travel of tourists, especially to local tourist destinations. \\
\hline Grain Marketing Board & The Grain Marketing Board is vital for ensuring food security in Zimbabwe and needs to be efficient. \\
\hline National Oil Infrastructure Company & $\begin{array}{l}\text { Fuel is vital in any economy, and determines the price of basic commodities. Efficiency in the SC performance of the National } \\
\text { Oil Infrastructure Company is vital. }\end{array}$ \\
\hline National Railways of Zimbabwe & $\begin{array}{l}\text { This SOE is vital for cheap and efficient transportation of bulk goods. In light of fuel price increases, the SC performance of the } \\
\text { National Railways of Zimbabwe is vital. }\end{array}$ \\
\hline Zimbabwe Electricity Supply Authority & $\begin{array}{l}\text { Electricity is one of the major sources of power for both industrial and domestic clients. This SOE is vital for economic } \\
\text { development. }\end{array}$ \\
\hline Zimbabwe National Water Authority & $\begin{array}{l}\text { The Zimbabwe National Water Authority has a mandate to regulate the use and provision of water. Climate change has resulted } \\
\text { in scarcity of water, which calls for efficiency and effectiveness in the operations of the Zimbabwe National Water Authority. }\end{array}$ \\
\hline Zimbabwe Mining Development Corporation & $\begin{array}{l}\text { Mining is becoming one of the largest contributors to Zimbabwe's GDP. Efficiency and effectiveness in the operations of the } \\
\text { Zimbabwe Mining Development Corporation are vital. }\end{array}$ \\
\hline Zimbabwe United Passenger Company & $\begin{array}{l}\text { The Zimbabwe United Passenger Company is vital for the transportation of passengers. It could also be instrumental in the } \\
\text { provision of affordable and reliable urban transport; hence it needs to be efficient. }\end{array}$ \\
\hline
\end{tabular}

SOE, State-owned enterprise; SC, Supply chain.

the organisational culture and SC performance metrics. The questions in the interview guide were directed to the managers and solicited information pertaining to the performance of the SOEs.

During the primary data collection stage, the researcher observed several ethical considerations such as informing the participants about the study, ensuring confidentiality and protecting the participants from harm. Statistical Package for Social Sciences (SPSS) was used to analyse statistical data and to compute frequency distribution tables. Qualitative data were analysed using thematic analysis. Data presentation started with descriptive presentations and the discussion of the statistics was fused with the qualitative findings from the interviews.

\section{Findings}

Ineffective SC performance in SOEs was a result of the culture, which did not encourage productivity, especially dimensions such as time, profit and ownership orientations. Findings of the study are presented thematically, in line with the research objectives.

\section{Supply chain performance in state-owned enterprises}

To assess the SC performance in the SOEs, the extent to which the financial targets were met was examined. Table 2 shows the results of SOE performance in meeting financial targets.

According to Table 2, it was established that all eight SOEs failed to meet financial targets, were sustaining losses, and were draining the treasury. State-owned enterprises like the GMB and NRZ were failing to pay their employees' salaries because of their inability to meet financial obligations. Accordingly, the level of employee motivation was very low. The inability of some of the SOEs to pay salaries resulted in government intervention. For example, in 2010, the treasury transferred more than $\$ 20 \mathrm{~m}$ to Air Zimbabwe so that the entity could pay employees who were on industrial action (Biti 2011). Further, interviews with some senior managers in the SOEs revealed that it was difficult to find partners owing to the negative balance sheets of some of the SOEs.
TABLE 2: Responses on the ability of state-owned enterprises to meet financial targets.

\begin{tabular}{|c|c|c|c|c|c|c|}
\hline \multirow[t]{2}{*}{ Variable } & \multicolumn{5}{|c|}{ Level of meeting targets by the SOEs } & \multirow[t]{2}{*}{ Total } \\
\hline & $<20 \%$ & $20 \%-40 \%$ & $41 \%-60 \%$ & $61 \%-80 \%$ & $81 \%-100 \%$ & \\
\hline \multicolumn{7}{|c|}{ Managerial } \\
\hline Count & 30 & 40 & 40 & 12 & 7 & 129 \\
\hline$\%$ & 23.3 & 31.0 & 31.0 & 9.3 & 5.4 & 100.0 \\
\hline \multicolumn{7}{|c|}{ Non-managerial } \\
\hline Count & 45 & 53 & 80 & 48 & 23 & 249 \\
\hline$\%$ & 18.1 & 21.3 & 32.1 & 19.3 & 9.2 & 100.0 \\
\hline \multicolumn{7}{|c|}{ Participant did not specify whether managerial or non-managerial } \\
\hline Count & 1 & 2 & 0 & 0 & 0 & 3 \\
\hline$\%$ & 33.3 & 66.7 & 0.0 & 0.0 & 0.0 & 100.0 \\
\hline \multicolumn{7}{|l|}{ Total } \\
\hline Count & 76 & 95 & 120 & 60 & 30 & 381 \\
\hline$\%$ & 19.9 & 24.9 & 31.5 & 15.7 & 7.9 & 100.0 \\
\hline
\end{tabular}

SOEs, State-owned enterprises.

Interviews with the managers showed that the SOEs were failing to meet financial targets because operating costs were not sustainable. It was indicated that equipment in use was not efficient and there were operational losses. Most participants were of the view that there was no relationship between remuneration and performance. Salaries and bonuses were paid irrespective of whether the organisations made profits or losses. Managers and employees were not motivated to 'perform' because they were always paid their bonuses even when their performance was not acceptable. State-owned enterprises were known for paying 'mega' salaries to management, which were not related to profits. State-owned enterprises were placing importance on the payment of salaries at the expense of service delivery. One of the causes of this state of affairs was a deterioration of the corporate governance system. Therefore, SOEs were largely affected by ineffective corporate governance practices, which led to corruption, especially in procurement. Senior management were not respecting the principles of sound corporate governance, like transparency and accountability.

In addition, in terms of internal business processes, they were failing to acquire appropriate equipment. Figure 3 illustrates the findings on the ability of the SOEs in meeting their equipment requirements.

The study also examined the extent to which the SOEs were innovative (Figure 4). 


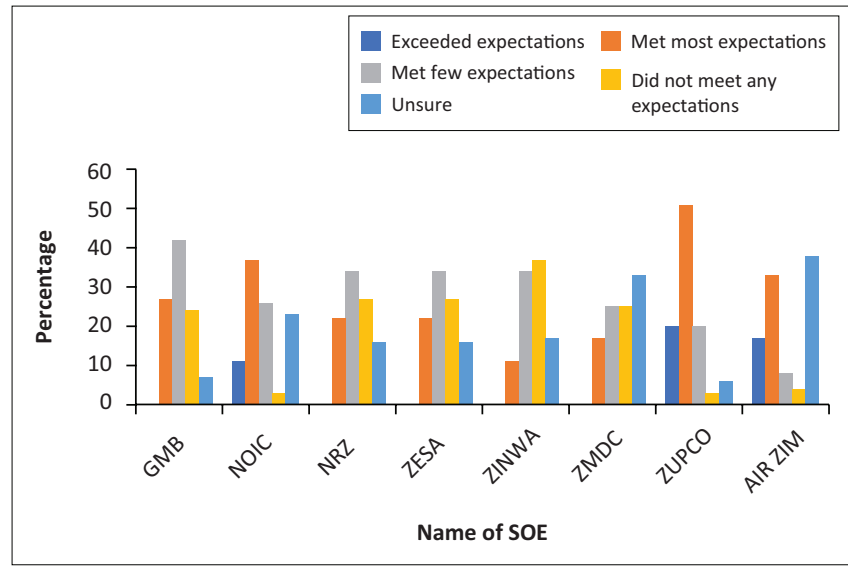

SOE, State-owned enterprise; GMB, Grain Marketing Board; NOIC, National Oil Infrastructure Company; NRZ, National Railways of Zimbabwe; ZESA, Zimbabwe Electricity Supply Authority; ZINWA, Zimbabwe National Water Authority; ZMDC, Zimbabwe Mining Development Corporation; ZUPCO, Zimbabwe United Passenger Company; AIR ZIM, Air Zimbabwe.

FIGURE 3: Responses on the view that state-owned enterprises met most of their equipment requirements.

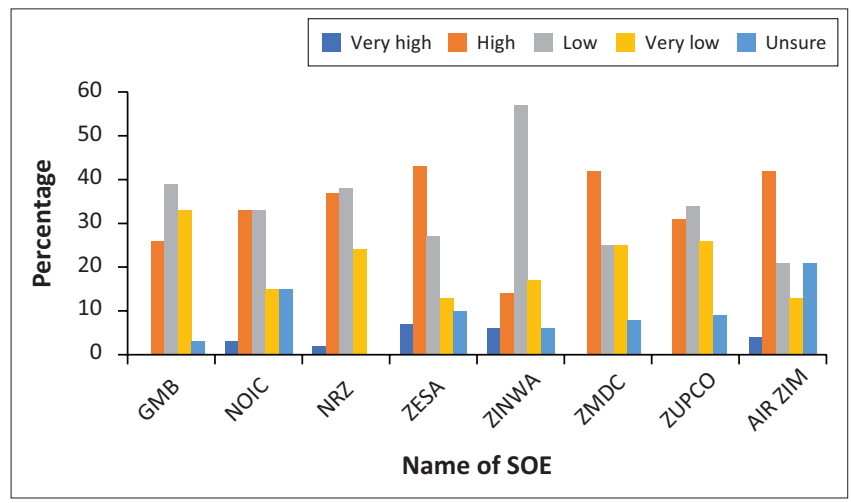

SOE, State-owned enterprise; GMB, Grain Marketing Board; NOIC, National Oil Infrastructure Company; NRZ, National Railways of Zimbabwe; ZESA, Zimbabwe Electricity Supply Authority; ZINWA, Zimbabwe National Water Authority; ZMDC, Zimbabwe Mining Development Corporation; ZUPCO, Zimbabwe United Passenger Company; AIR ZIM, Air Zimbabwe.

FIGURE 4: Responses on individual innovation in the state-owned enterprises.

Innovation was lacking in the SOEs because of the lack of employee empowerment, which could in turn have been hampering SC performance. It should be noted that employee empowerment, which encourages innovation, is different from employee participation. Finally, it was established that the SOEs were able to allocate resources for training and development, although innovation was lacking. The study also showed that employee empowerment, satisfaction of clients and organisational development were necessary for the improvement of SC performance in SOEs.

\section{Influence of time orientation on the supply chain metric of delivery in state-owned enterprises in Zimbabwe}

The participants were requested to comment on the level of effort made by organisational members to ensure that deadlines were met. The findings are presented in Figure 5.

The findings in Figure 5 show that the products and services were not delivered on time. When there is a delay in service

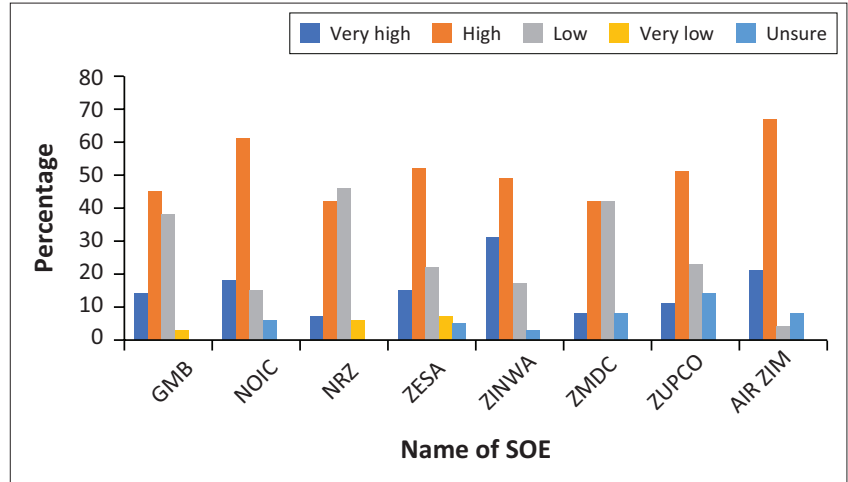

SOE, State-owned enterprise; GMB, Grain Marketing Board; NOIC, National Oil Infrastructure Company; NRZ, National Railways of Zimbabwe; ZESA, Zimbabwe Electricity Supply Authority; ZINWA, Zimbabwe National Water Authority; ZMDC, Zimbabwe Minin Development Corporation; ZUPCO, Zimbabwe United Passenger Company; AIR ZIM, Air Zimbabwe.

FIGURE 5: Response on the level of effort by organisational members to meet deadlines.

delivery, an SOE loses customer goodwill and clients are forced to look for alternative service providers. Stateowned enterprises that are operating in competitive or deregulated environments, like Air Zimbabwe, the National Oil Infrastructure Company, NRZ and Zimbabwe United Passenger Company, are losing clients to other service providers. Weak organisational culture was largely responsible for ineffective organisational performance. It was established that some SOEs had improved on meeting deadlines, while others were still facing challenges. Delays in decision-making and action have been a characteristic of most SOEs. In some SOEs, no meaningful effort was being made by the organisational members, because they were demotivated about not being paid on time, no longer enjoying nonmonetary benefits and not having resources to use. The study also established that SOEs require effective leadership to facilitate efficient turnaround.

\section{Influence of time orientation on the supply chain metric of flexibility in state-owned enterprises in Zimbabwe}

The study examined the extent to which the SOEs were using time management tools. Table 3 shows responses on the use of Gantt charts and network analysis.

Table 3 shows that the SOEs were not making extensive use of time management. This was not a healthy situation, because time is an important resource that needs effective management. This failure to use time management tools could also explain the delays in service delivery.

\begin{tabular}{|c|c|c|c|c|c|c|}
\hline Tools & $\begin{array}{c}\text { Always } \\
\text { (1) }\end{array}$ & $\begin{array}{c}\text { Sometimes } \\
\text { (2) }\end{array}$ & $\begin{array}{l}\text { Not often } \\
\text { (3) }\end{array}$ & $\begin{array}{l}\text { Rarely } \\
\text { (4) }\end{array}$ & $\begin{array}{l}\text { Unsure } \\
(5)\end{array}$ & Total \\
\hline \multicolumn{7}{|c|}{ Gantt charts } \\
\hline Count & 53 & 116 & 71 & 62 & 139 & 441 \\
\hline$\%$ & 12.0 & 26.3 & 16.1 & 14.1 & 31.5 & 100.0 \\
\hline \multicolumn{7}{|c|}{ Network analysis } \\
\hline Count & 65 & 106 & 72 & 64 & 137 & 3.48 \\
\hline$\%$ & 14.6 & 23.9 & 16.2 & 14.4 & 30.9 & 100.0 \\
\hline
\end{tabular}


The study collected data on whether SOEs were able to provide personalised services. The provision of tailor-made services is a way of responding to the specific expectations of clients. In addition, tailor-made products and services can be offered at a premium price, making it possible to generate extra revenue. The findings on whether SOEs are able to provide personalised products and services are presented in Table 4.

Table 4 shows that $46.4 \%$ (less than half) of the participants supported the view that the SOEs were providing personalised services. Therefore, one could conclude that, at the time of this research, the SOEs under study engaged in mass marketing of similar products and did not cater for special needs. The findings from interviews suggested that flexibility is a challenge in the SOEs being studied. It was established, however, that creativity is encouraged in some of the SOEs, and this facilitates openness to change and adaptation. Table 5 shows the findings on creativity.

Table 5 shows that $67 \%$ of the managers and $60 \%$ of the employees agreed that creativity was encouraged in some of the SOEs. It is essential to encourage creativity and entrepreneurship in the SOEs.

\section{Influence of profit orientation on cost reduction in supply chain activities in state-owned enterprises in Zimbabwe}

The study showed that SOEs were not efficient; there were no cost control measures, and they were not sustainable. One of the reasons is that there are no-ownership claims

TABLE 4: Participants' responses on provision of personalised products and services.

\begin{tabular}{lcccccc}
\hline Variable & $\begin{array}{c}\text { Strongly } \\
\text { agree (1) }\end{array}$ & $\begin{array}{c}\text { Agree } \\
\text { (2) }\end{array}$ & $\begin{array}{c}\text { Disagree } \\
\text { (3) }\end{array}$ & $\begin{array}{c}\text { Strongly } \\
\text { disagree (4) }\end{array}$ & $\begin{array}{c}\text { Unsure } \\
\text { (5) }\end{array}$ & Total \\
\hline $\begin{array}{l}\text { Managerial } \\
\text { Count }\end{array}$ & 14 & 38 & 37 & 6 & 7 & 102 \\
$\%$ & 13.7 & 37.3 & 36.3 & 5.9 & 6.9 & 100.0 \\
$\begin{array}{l}\text { Non-managerial } \\
\text { Count }\end{array}$ & 11 & 55 & 46 & 5 & 35 & 152 \\
$\%$ & 7.2 & 36.2 & 30.3 & 3.3 & 23.0 & 100.0 \\
\hline $\begin{array}{l}\text { Total } \\
\text { Count }\end{array}$ & $\mathbf{2 5}$ & $\mathbf{9 3}$ & $\mathbf{8 3}$ & $\mathbf{1 1}$ & $\mathbf{4 2}$ & $\mathbf{2 5 4}$ \\
$\%$ & $\mathbf{9 . 8}$ & $\mathbf{3 6 . 6}$ & $\mathbf{3 2 . 7}$ & $\mathbf{4 . 3}$ & $\mathbf{1 6 . 5}$ & $\mathbf{1 0 0 . 0}$ \\
\hline
\end{tabular}

TABLE 5: Participants' response to the view that state-owned enterprises encourage creativity.

\begin{tabular}{lcccccc}
\hline Variable & $\begin{array}{c}\text { Strongly } \\
\text { agree (1) }\end{array}$ & $\begin{array}{c}\text { Agree } \\
\text { (2) }\end{array}$ & $\begin{array}{c}\text { Disagree } \\
\text { (3) }\end{array}$ & $\begin{array}{c}\text { Strongly } \\
\text { disagree (4) }\end{array}$ & $\begin{array}{c}\text { Unsure } \\
\text { (5) }\end{array}$ & Total \\
\hline $\begin{array}{l}\text { Managerial } \\
\text { Count }\end{array}$ & 13 & 56 & 23 & 6 & 3 & 101 \\
$\%$ & 12.9 & 55.4 & 22.8 & 5.9 & 3.0 & 100.0 \\
$\begin{array}{l}\text { Non-managerial } \\
\text { Count }\end{array}$ & 28 & 64 & 35 & 10 & 15 & 152 \\
$\%$ & 18.4 & 42.1 & 23.0 & 6.6 & 9.9 & 100.0 \\
\hline Total & & & & & & \\
Count & 41 & 120 & 58 & 16 & 18 & 2.51 \\
$\%$ & 16.2 & 47.4 & $\mathbf{2 2 . 9}$ & 6.3 & $\mathbf{7 . 1}$ & 100.0 \\
\hline
\end{tabular}

to profit. The ownership structure influences the extent to which management is committed towards realising profits. State-owned enterprises, by virtue of being owned by government, are characterised by the no-ownership culture, thereby limiting drive towards profits. It was found that the equipment in use was not efficient, and there were losses during operations. Table 6 shows the findings on cost savings in the SOEs.

Some SOEs were adopting cost-saving strategies such as cutting salaries. However, remuneration was not based on performance, and management was accused of receiving 'mega' salaries. It was held that the SOEs did not have sound debt management strategies.

The study further established the extent to which SOEs were able to implement debt management strategies. Sound debt management is essential in any institution. Table 7 shows the findings on debt management.

According to Table 7 , only $26 \%$ of the managers said that there were effective debt management strategies. Further, only $33 \%$ of the employees agreed that SOEs were efficient at collecting debts.

The absence of a profit orientation culture prevents SOEs from identifying ways to improve efficiency. Managers in SOEs tend to relax because low revenues can be 'compensated' for by government bailouts and subsidies. Efforts to enhance performance are not given priority, and weak accountability systems prevent the development of an ownership structure that would promote efficient behaviour from senior management.

TABLE 6: Participants' response on adoption of cost-saving strategies.

\begin{tabular}{lcccccc}
\hline Variable & $\begin{array}{c}\text { Strongly } \\
\text { agree (1) }\end{array}$ & $\begin{array}{c}\text { Agree } \\
\text { (2) }\end{array}$ & $\begin{array}{c}\text { Disagree } \\
\text { (3) }\end{array}$ & $\begin{array}{c}\text { Strongly } \\
\text { disagree (4) }\end{array}$ & $\begin{array}{c}\text { Unsure } \\
\text { (5) }\end{array}$ & Total \\
\hline $\begin{array}{l}\text { Managerial } \\
\text { Count }\end{array}$ & 55 & 26 & 10 & 4 & 7 & 102 \\
$\%$ & 53.9 & 25.5 & 9.8 & 3.9 & 6.9 & 100.0 \\
$\begin{array}{l}\text { Non-managerial } \\
\text { Count }\end{array}$ & 81 & 46 & 9 & 7 & 9 & 152 \\
$\%$ & 53.3 & 30.3 & 5.9 & 4.6 & 5.9 & 100.0 \\
\hline $\begin{array}{l}\text { Total } \\
\text { Count }\end{array}$ & 136 & $\mathbf{7 2}$ & $\mathbf{1 9}$ & $\mathbf{1 1}$ & 16 & $\mathbf{2 5 4}$ \\
$\%$ & $\mathbf{5 3 . 5}$ & $\mathbf{2 8 . 3}$ & $\mathbf{7 . 5}$ & $\mathbf{4 . 3}$ & $\mathbf{6 . 3}$ & $\mathbf{1 0 0 . 0}$ \\
\hline
\end{tabular}

TABLE 7: Participants' responses on the view that debt management strategies are effective.

\begin{tabular}{lcccccc}
\hline Variable & $\begin{array}{c}\text { Strongly } \\
\text { agree (1) }\end{array}$ & $\begin{array}{c}\text { Agree } \\
\text { (2) }\end{array}$ & $\begin{array}{c}\text { Disagree } \\
\text { (3) }\end{array}$ & $\begin{array}{c}\text { Strongly } \\
\text { disagree (4) }\end{array}$ & $\begin{array}{c}\text { Unsure } \\
\text { (5) }\end{array}$ & Total \\
\hline $\begin{array}{l}\text { Managerial } \\
\text { Count }\end{array}$ & 5 & 21 & 49 & 21 & 5 & 102 \\
$\%$ & 4.9 & 20.6 & 48.0 & 20.6 & 4.9 & 100.0 \\
$\begin{array}{l}\text { Non-managerial } \\
\text { Count }\end{array}$ & 16 & 34 & 63 & 14 & 26 & 153 \\
$\%$ & 10.5 & 22.2 & 41.2 & 9.2 & 17.0 & 100.0 \\
\hline Total & & & & & & \\
Count & 21 & 55 & 112 & 35 & 31 & 255 \\
$\%$ & 8.2 & 21.6 & 43.9 & 13.7 & 12.2 & 100.0 \\
\hline
\end{tabular}




\section{Influence of 'no owner' culture on decision- making in supply chain management in state- owned enterprises in Zimbabwe}

Interviews with the managers showed that employees were reluctant to work overtime when there was no allowance. Moreover, the study showed that there were challenges relating to procurement and that most of the people tasked with the responsibility of procuring resources were incompetent. The study also showed that lower-level employees were not 'allowed' to make the decisions affecting duties assigned to them. The present study further collected data on whether employees were encouraged to make suggestions on ways to reduce costs. The findings are presented in Table 8.

According to Table 8 , more than $70 \%$ of the managers were in agreement with the assertion that employees should participate in decision-making. Additionally, Table 8 shows that $63 \%$ of the employee respondents either strongly agreed or agreed that they were allowed to participate in the making of decisions. The research showed that there was no consultation with lower-level staff in decision-making, and if there was, it occurred after resolutions were made. Moreover, one of the factors affecting effective decision-making in the SOEs was ineffective corporate governance. The study noted that the management of SOEs is solely in the hands of government; there is a danger of unjust and inflexible implementation of policies and procedures. Centralisation of power will manifest as gross corruption and poor service delivery. Political interference in the management of SOEs was a major challenge.

\section{Level of customer satisfaction in state-owned enterprises}

The study sought to establish the extent of customer satisfaction in the SOEs. The findings are presented in Table 9.

Table 9 shows that there was convenience in terms of SOE products and services and the prices and quality of the products were acceptable. However, there were low levels of courtesy in these organisations. Some SOEs were not responsive to customer complaints. For instance, it was established that customer complaints or fault reports are gathering dust in the Zimbabwe Electricity Transmission and Distribution Company (ZETDC) offices unattended.

TABLE 8: Participants' responses on the view that employees make recommendations on cost reduction.

\begin{tabular}{lcccccc}
\hline Variable & $\begin{array}{c}\text { Strongly } \\
\text { agree (1) }\end{array}$ & $\begin{array}{c}\text { Agree } \\
\text { (2) }\end{array}$ & $\begin{array}{c}\text { Disagree } \\
\text { (3) }\end{array}$ & $\begin{array}{c}\text { Strongly } \\
\text { disagree (4) }\end{array}$ & $\begin{array}{c}\text { Unsure } \\
\text { (5) }\end{array}$ & Total \\
\hline $\begin{array}{l}\text { Managerial } \\
\text { Count }\end{array}$ & 21 & 56 & 17 & 7 & 1 & 102 \\
$\%$ & 20.6 & 54.9 & 16.7 & 6.9 & 1.0 & 100.0 \\
$\begin{array}{l}\text { Non-managerial } \\
\text { Count }\end{array}$ & 33 & 63 & 35 & 9 & 12 & 152 \\
$\%$ & 21.7 & 41.4 & 23.0 & 5.9 & 7.9 & 100.0 \\
\hline $\begin{array}{l}\text { Total } \\
\text { Count }\end{array}$ & $\mathbf{5 4}$ & 119 & $\mathbf{5 2}$ & $\mathbf{1 6}$ & $\mathbf{1 3}$ & $\mathbf{2 5 4}$ \\
$\%$ & $\mathbf{2 1 . 3}$ & $\mathbf{4 6 . 9}$ & $\mathbf{2 0 . 5}$ & $\mathbf{6 . 3}$ & $\mathbf{5 . 1}$ & $\mathbf{1 0 0 . 0}$ \\
\hline
\end{tabular}

Zimbabwe Electricity Transmission and Distribution Company is a subsidiary of ZESA, which is concerned with distribution of electricity to the clients. However, the subsidiary is failing to provide normal electricity to its consumers, and in return they are billed with excessive figures that are not commensurate with their consumption. There are several cases where people have lost their lives or have been maimed after being electrocuted by live electricity cables left idle as a result of poor workmanship. Zimbabwe Electricity Transmission and Distribution Company has also experienced vandalism to its infrastructure by its own employees, thereby compromising its service to its customers. Additionally, the research showed that there was no consultation of clients when SOEs made decisions affecting stakeholders. Delays in decision-making and action have been a characteristic of most SOEs and this affected service delivery. It was established that in some SOEs, no meaningful efforts were made by the organisational members, because they were demotivated as a result of not being paid on time, no longer enjoying non-monetary benefits and lacking resources to use.

\section{Recommendations}

The following are recommendations to ensure improvement of organisational culture and SC performance in SOEs:

- Committed leadership is essential for effective strategy implementation in SOEs. This study recommends that performance-based remuneration be introduced for senior managers. The leaders should also behave ethically and uphold principles of sound corporate governance.

- Staff training is recommended to ensure effective SC performance. The use of time management tools is also recommended to ensure effectiveness in time orientation. In addition, the leaders in SOEs need to involve staff in strategy formulation, to ensure that employees have more understanding and ownership of strategies.

- It is recommended that SOEs constantly carry out environmental scanning in order to avoid surprises, identify threats and opportunities, gain competitive advantage and improve long-term and short-term planning.

TABLE 9: Participants' responses on customer satisfaction in the state-owned enterprises.

\begin{tabular}{lcccccc}
\hline $\begin{array}{l}\text { Element of customer } \\
\text { satisfaction }\end{array}$ & $\begin{array}{c}\text { Strongly } \\
\text { agree }\end{array}$ & Agree & Disagree & $\begin{array}{c}\text { Strongly } \\
\text { disagree }\end{array}$ & Unsure & Total \\
\hline $\begin{array}{l}\text { Convenience } \\
\text { Count }\end{array}$ & 82 & 164 & 22 & 36 & 13 & 317 \\
$\%$ & 25.9 & 51.7 & 6.9 & 11.4 & 4.1 & 100.0 \\
$\begin{array}{l}\text { Courtesy } \\
\text { Count }\end{array}$ & 32 & 67 & 98 & 78 & 42 & 317 \\
$\%$ & 10.1 & 21.1 & 30.9 & 24.6 & 13.2 & 100.0 \\
$\begin{array}{l}\text { Transactions methods and systems } \\
\text { Count }\end{array}$ & 193 & 104 & 0 & 1 & 19 & 317 \\
$\quad \%$ & 60.9 & 32.8 & 0.0 & 0.3 & 6.0 & 100.0 \\
$\begin{array}{l}\text { Affordability } \\
\text { Count }\end{array}$ & 23 & 141 & 41 & 13 & 99 & 317 \\
$\quad \%$ & 7.3 & 44.5 & 12.9 & 4.1 & 31.2 & 100.0 \\
Quality & & & & & & \\
$\quad \begin{array}{l}\text { Count } \\
\%\end{array}$ & 71 & 105 & 60 & 23 & 58 & 317 \\
\hline
\end{tabular}


- The study showed that salaries and benefits were not in line with performance. Because salaries constitute a major cost in SOEs, remuneration should be in line with performance.

- Accountability and transparency are essential in SOEs. There has been a growing requirement for SOEs around the world to meet reporting and disclosure requirements as regards financial information, as well as environmental, social and governance data.

- The study recommends the effective separation of the government's role as an owner of the SOEs and its role as regulator, particularly with regard to market regulation. There is a need for the government of Zimbabwe to adopt a highly centralised or coordinated approach to managing its ownership function in SOEs. It should enact legislation, establishing a new central ownership agency that will be responsible for ownership functions, which can then be separated from the state's other functions in the SOEs.

- The study found that there was political interference in the operations of the SOEs being studied and therefore recommends that the respective ministries and authorities shun political interference.

- The study showed that all SOEs failed to improve their business processes and were unable to acquire efficient machinery. There is therefore need for re-engineering, so that SOEs are able to improve service delivery.

- The research showed that SOEs were not able to provide services that were in line with the needs of the clients. It is therefore recommended that these institutions become market-oriented and respond to the needs of clients.

\section{Suggestions for further study}

The study found that most of the challenges in SOEs relate to the corporate governance culture. There is therefore a need for a study to assess the improvements in corporate governance in SOEs, where ownership structure has a huge bearing on SC performance. Therefore, it might be necessary to revisit the privatisation debate. The state might need to 'roll back' its frontiers again. However, informed decisions, through research, are essential.

\section{Conclusion}

Based on the conceptualised study within the framework illustrated in Figure 2, the study found that organisational cultural variables such as time, ownership and profit orientation have a direct influence on the behaviour of human resources and a resultant influence on customer satisfaction, cost savings and profitability in the SOEs. The research found that the SOEs in Zimbabwe had a similar culture, which did not promote productivity, especially dimensions such as time, profit and ownership orientation. There was ineffective application of business strategies, a lack of capitalisation, political influence, bureaucracy and low employee motivation. Despite adverse performance, SOEs continued to reward managers 'handsomely', and there did not appear to be any effort to align managerial remuneration with performance. For instance, the senior managers in the SOEs were accused of receiving 'mega-salaries', in a development that was labelled 'Salarygate'.

The fact that managers or employees of SOEs do not have a stake in the ownership of these organisations has led to the development of negative attitudes and irresponsible behaviour towards the execution of activities. This adverse human behaviour has resulted in most of the SOEs failing to meet performance targets. In addition, employees do not have the motive or self-encouragement to work hard or to be innovative in order to contribute positively to the organisational goals. The no-ownership culture is deeply rooted in the employees' mindsets because it means that no individual is answerable for poor performance.

\section{Acknowledgements Competing interests}

The authors declare that they have no financial or personal relationships that may have inappropriately influenced them in writing this article.

\section{Authors' contributions}

M.M. researched the topic and delivered the results, recommendations and conclusions. M.R. provided guidance on the development of the topic and structure of the thesis and ensured that the results, recommendations and conclusions satisfied the objectives of the research study.

\section{Funding information}

The University of KwaZulu-Natal provided a grant to the researcher to carry out the $\mathrm{PhD}$ research study.

\section{References}

Allio, M.K., 2005, 'A short, practical guide to implementing strategy', The Journal of Business Strategy 9(1), 123-135. https://doi.org/10.1108/02756660510608512

Armstrong, M., 2008, Strategic human resource management: $A$ guide to action, 4th edn., Kogan Page, London.

Baily, P., Farmer, D., Jessop, D. \& Jonnes, D., 2008, Procurement principles and management, Pearson Education, New York.

Bhagwat, R. \& Sharma, M.K., 2007, 'Performance measurement of supply chain management: A balanced scored card approach', Computers and Industrial Engineering 53(1), 43-62.

Biti, T., 2011, Performance of the capital budget as at 30 April 2011, Ministry of Finance, Harare.

Bose, S. \& Thomas, K., 2007, 'Applying the balanced scorecard for better performance of intellectual capital', Journal of Intellectual Capital 8(4), 653-665. https://doi. org/10.1108/14691930710830819

Burman, R. \& Evans, A.J., 2008, 'Target zero: A culture of safety', Defence Aviation Safety Culture Journal 5(2), 112-137.

Chandrasekaran, N., 2010, Supply chain management, Oxford University Press, New York. Chemangich, W., 2013, 'Decentralisation debate in Africa', Journal of Sustainable Development in Africa 12(1), 201-211.

Chin, K.S., 2010, An empirical study on quality management, Wiley, New York.

Clarke, T., 2007, International corporate governance: A comparative approach, Routledge, London.

Creswell, J.W., 2014, Research design: Quantitative, qualitative, and mixed methods approaches, 4th edn., Sage, Thousand Oaks, CA.

Denzin, M., 2008, 'Quality in retail banking', International Journal of Service Industry Management 5(2), 5-23. 
Dessler, G., 2005, Human resources management, 10th edn., Prentice Hall of India, New Delhi.

Grant, R.M., 2008, Contemporary strategy analysis, 6th edn., Blackwell, Oxford.

Islam, G. \& Michael, Z., 2009, Rituals in organisations: A review and expansion of current theory, Group Organisational Management, Cambridge.

Jerome, A., 2008, 'Privatisation and enterprise performance in Nigeria: Case study of some privatised enterprises', Research Paper 175, African Economic Research Consortium, Nairobi.

Johnson, P. \& Scholes, T., 2010, Strategic management, 5th edn., Pearson, London.

Kaplan, R.S. \& Norton, D.P., 1992, 'The balances scorecard: Measures that drive performance', Harvard Business Review 25(1), 103-125.

Kim, H.S., 2007, 'An empirical analysis on the economic performance of privatized public firms in Korea', Korea Journal of Public Finance 22(1), 35-60.

Lambert, D., 2008, Supply chain management: Processes, partnerships, and performance, 3rd edn., Elsevier, Oxford.

Lamikanra, S., 2013, African Banking Industry Customer Satisfaction Survey, KPMG, Lagos.

Larbi, R., 2006, New public management in African SOEs, The World Bank Washington, DC.

Mafumbe, I., 2011, 'Parastatals: Throwing good money after bad', The Financial Gazette, 21 October, p. 8.

Masuku, J., 2011, 'The public broadcaster model and the ZBC: An analytical study', Unpublished master's thesis, Stellenbosch University, Stellenbosch.

Mehrjerdi, Y.Z., 2009, 'Excellent supply chain management', Assembly Automation 29(1), 52-60. https://doi.org/10.1108/01445150910929866

Nambirijan, T. \& Kumar, C.G., 2010, Measurement of performance of supply chain and their impact on the competitiveness of manufacturing industries in the union territory of Pondicherry, India, University of Kelaniya, Sri Lanka.

Nyoni, E., 2012, Restructuring procedures manual, Printflow, Harare.

Omoyefa, P.S., 2008, 'Public sector reforms in Africa: A philosophical re-thinking', Africa Development 33(4), 15-30.

Parasuraman, A., Zeithamal, B. \& Berry, T., 1985, Service marketing perspective, Prentice-Hall, New York.

Peterson, D., 2012, 'Knowledge retention strategies in selected southern African public broadcasting corporations', Unpublished doctoral thesis, University of Fort Hare, Fort Hare.
Quy, V.T., 2011, Organisational culture of privatised firms and state owned enterprises in Vietnam, University of Economics, HoChi Minh City.

Ralston, O.A., Tong, J., Terpstra, R.H., Wang, X. \& Egri, C., 2008, 'Today's state owned enterprises in China: Are they dying dinosaurs or dynamic dynamos', Journal of International Management 15(3), 121-160.

Ravasi, D. \& Schultz, M., 2006, 'Responding to organisational identity threats: Exploring the role of organisational culture', Academy of Management Journal 30(1), 108-129.

Research Advisory Council, 2006, Required sample size, viewed 07 October 2013, from http://www.research-advisors.com

Reserve Bank of Zimbabwe, 2009, Evoking supply side response through privatisation and foreign currency generation, Fidelity Printers, Harare.

Rondinelli, D.A., 2005, 'Can public enterprises contribute to development: A critical assessment and alternatives for management improvement', Paper prepared for the United Nations Expert Group Meeting on Reinventing Public Enterprise Management, New York, 28 October.

Saunders, M., Lewis, P. \& Thornhill, A., 2012, Research methods for business students, 6th edn., Prentice-Hall, London.

Schein, E.H., 2009, Organisational culture and leadership: A dynamic view, 6th edn., Jossey-Bass, San Francisco, CA.

Schein, E.H., 2010, Organisational culture and leadership, 4th edn., Wiley, San Francisco, CA

Schlettwein, C., 2010, Assessing the performance of state owned enterprises in Namibia: Financial regulatory point of view, Namibian Economic Society, Windhoek.

Sekeran, U. \& Bourgie, R., 2010, Research methods for business: A skill building approach, 6th edn., Wiley, New York.

Shahzad, F., Luqman, R.A. \& Khan, A.R., 2012, 'Impact of organisational culture on organisational performance: An overview', Interdisciplinary Journal of Contemporary Research in Business 3(9), 975-985.

The Zimbabwe Independent, 2013, 'SOEs continue to makes losses', 1 August, viewed 01 July 2014, from http://www.theindependent.co.zw

Wieland, A. \& Wallenburg, C.M., 2011, Supply chain management, Zeiten, Berlin.

Woetzel, J.R., 2008, Reassessing China's state owned enterprises, McKinsey, New York.

Zhang, X., 2009, Values, expectations, adhoc rules and culture emergence in international cross cultural management contexts, Nova Science, New York.

Zimbabwe National Statistical Agency, 2012, National statistics, viewed 01 December 2013, from http://www.zimstats.co.zw 